\title{
Glycine Transporter-1 Controls Nonsynaptic Inhibitory Actions of Glycine Receptors in the Neonatal Rat Hippocampus
}

\author{
Sampsa T. Sipilä, ${ }^{1,2,3}$ Albert Spoljaric, ${ }^{3,4}$ Mari A. Virtanen, ${ }^{3}$ Inkeri Hiironniemi, ${ }^{3}$ and Kai Kaila ${ }^{3,4}$ \\ ${ }^{1}$ Department of Physiology, Faculty of Medicine, University of Oulu, FIN-90220 Oulu, Finland, ${ }^{2}$ Department of Clinical Neurophysiology, Oulu University \\ Hospital, FIN-90220 Oulu, Finland, and ${ }^{3}$ Department of Biosciences and ${ }^{4}$ Neuroscience Center, University of Helsinki, 00014 Helsinki, Finland
}

\begin{abstract}
Although functional glycinergic synapses have not been identified in the hippocampus, neurons in this area express $\mathrm{Cl}^{-}$permeable extrasynaptic glycine receptors (GlyRs). In experiments on CA3 pyramidal neurons on postnatal day 0-6 rat hippocampal slices, we detected robust GlyR activity as a tonic current and as single-channel events. Glycine release was independent of neuronal activity or extracellular $\mathrm{Ca}^{2+}$. The endogenous GlyR activity was strongly enhanced by inhibition of the glycine-transporter-1 (GlyT1). Blockade of GlyT1 also caused a profound increase in the baseline current induced by exogenous glycine. Inhibition of GlyT1 reduced the frequency of spontaneous network events known as field giant depolarizing potentials (fGDPs) and of the unit activity in the absence of synaptic transmission. This inhibitory action on fGDPs was mimicked by applying $2 \mu \mathrm{m}$ glycine or $0.1 \mu \mathrm{m}$ isoguvacine, a $\mathrm{GABA}_{\mathrm{A}}$-receptor agonist. Furthermore, $2 \mu \mathrm{m}$ glycine suppressed unit spiking in the absence of synaptic transmission. Hence, despite the well known depolarizing $\mathrm{Cl}^{-}$equilibrium potential of neonatal hippocampal neurons, physiologically relevant extracellular glycine concentrations can exert an inhibitory action. The present data show that, akin to GABA uptake, GlyT1 exerts a powerful modulatory action on network events in the newborn hippocampus.
\end{abstract}

Key words: development; glycine; hippocampus; newborn; spontaneous activity; tonic

\section{Introduction}

The hippocampus is devoid of functional glycinergic synapses, but strychnine-sensitive anion-permeable glycine receptors (GlyRs) have been firmly identified and characterized in hippocampal neurons (Ito and Cherubini, 1991; Fatima-Shad and Barry, 1992; Chattipakorn and McMahon, 2002; Mori et al., 2002; Lynch, 2004; Betz and Laube, 2006; Song et al., 2006; Eichler et al., 2008;Keck et al., 2008; Xu and Gong, 2010). The importance of glycine-mediated neuronal signaling mechanisms becomes particularly salient under conditions that disrupt them, such as glycine encephalopathy (Korman and Gutman, 2002) and genetic knock-out of glycine transporters (Betz et al., 2006). Nevertheless, little is known about the roles of this major transmitter in the regulation of neuronal activity in the immature brain.

Received Jan. 4, 2013; revised June 5, 2014; accepted June 13, 2014.

Author contributions:S.T.S., M.A.V., and K.K. designed research;S.T.S., A.S., M.A.V., and I.H. performed research; S.T.S. analyzed data; S.T.S. and K.K. wrote the paper.

This work was supported by grants from the Academy of Finland, the Sigrid Jusélius Foundation, the Letten Foundation, and the Jane and Aatos Erkko Foundation (K.K.). We thank Kristiina Huttu for making a series of pilot experiments.

The authors declare no competing financial interests.

Correspondence should be addressed to Dr Kai Kaila, Department of Biosciences, and Neuroscience Center, University of Helsinki, P0 Box 65 (Viikinkaari 1, 00710 Helsinki), 00014 Helsinki, Finland. E-mail: Kai.Kaila@Helsinki.Fi.

M. A. Virtanen's present address: Neuroscience Center, University of Geneva, CH-1211 Geneva, Switzerland.

DOI:10.1523/JNEUROSCI.0075-13.2014

Copyright $\odot 2014$ the authors $\quad 0270-6474 / 14 / 3410003-07 \$ 15.00 / 0$
A powerful tonic activation of $\mathrm{GABA}_{\mathrm{A}}$ receptors $\left(\mathrm{GABA}_{\mathrm{A}} \mathrm{Rs}\right)$ commences before the development of functional synapses in the hippocampus (Valeyev et al., 1993; Owens et al., 1999; Demarque et al., 2002). The tonic GABA current is regulated by GABA transport (Marchionni et al., 2007; Sipilä et al., 2007). It modulates the gain of neuronal signaling and plays an important role in regulating network excitability (Semyanov et al., 2004; Farrant and Nusser, 2005; Brickley and Mody, 2012). Based on work in hippocampal organotypic slice cultures, taurine and $\beta$-alanine have been proposed to be endogenous agonists of GlyRs (Mori et al., 2002) and there is evidence for this role for taurine and glycine in the immature neocortex and spinal cord, respectively (Flint et al., 1998; Scain et al., 2010). Glycine-transporter-1 (GlyT1) regulates the extracellular concentration of glycine and is the main transport mechanism in the forebrain (Zafra et al., 1995; Gomeza et al., 2003). Interestingly, glycine is a co-agonist at NMDARs (Johnson and Ascher, 1987), thus both GlyRs and NMDARs can be subject to modulation by GlyT1 (Gomeza et al., 2003; Eulenburg et al., 2005; Zhang et al., 2008). However, it is not known whether endogenous activation of GlyRs and glycine transport via GlyT1 occurs in the immature hippocampus.

The neonatal hippocampus generates spontaneous network events known as giant depolarizing potentials (GDPs) in vitro and sharp wave-associated population bursts in vivo (Ben-Ari et al., 1989; Leinekugel et al., 2002; Mohns and Blumberg, 2008). Depolarizing GABAergic transmission promotes GDPs (Ben-Ari et al., 2007). Notably, GDPs are suppressed by NMDAR antagonists 
(Bolea et al., 1999) and the ability of glycine to promote GDP occurrence has been attributed to the glycine binding site of presynaptic NMDARs on GABAergic interneurons (Gaiarsa et al., 1990).

We studied the role of GlyRs in the regulation of spontaneous unit and network activity in neonatal rat hippocampal slices. Our data demonstrate a robust, endogenously activated tonic GlyRmediated conductance that is controlled by GlyT1. Both pharmacological inhibition of GlyT1 and application of low $(2 \mu \mathrm{M})$, physiologically relevant concentration of glycine (Choi et al., 1999; Korman and Gutman, 2002) exerted an inhibitory action on field GDPs and unit activity in the absence of synaptic transmission, despite the depolarizing $\mathrm{Cl}^{-}$driving force at this stage of hippocampal development (Ben-Ari et al., 2007; Blaesse et al., 2009).

\section{Materials and Methods}

In vitro slice preparation. Postnatal day $(\mathrm{P}) 0-\mathrm{P} 6$ Wistar rat pups of either sex were decapitated, and the brains were dissected in ice-cold $\left(0-4^{\circ} \mathrm{C}\right)$ oxygenated $\left(95 \% \mathrm{O}_{2}\right.$ and $\left.5 \% \mathrm{CO}_{2}\right)$ saline. For electrophysiological recordings, coronal and horizontal brain slices $(400 \mu \mathrm{m})$ were cut with a vibrating blade microtome (VT1000S; Leica). The slices were allowed to recover at least for $1 \mathrm{~h}$ at $32^{\circ} \mathrm{C}$ before use. Individual slices were transferred into a submersion-type recording chamber perfused with standard solution $\left(32-33^{\circ} \mathrm{C}\right)$, and anchored with platinum wires. The standard solution contained the following (in $\mathrm{mM}$ ): $124 \mathrm{NaCl}, 4.0 \mathrm{KCl}$, 2.0 $\mathrm{CaCl}_{2}, 25 \mathrm{NaHCO}_{3}, 1.1 \mathrm{NaH}_{2} \mathrm{PO}_{4}, 1.3 \mathrm{MgSO}_{4}$, and 10 D-glucose, $\mathrm{pH}$ 7.4 , at $32^{\circ} \mathrm{C}$. In the $0-\mathrm{Ca}^{2+}$ solution, $\mathrm{CaCl}_{2}$ was omitted, $\mathrm{MgSO}_{4}$ was raised to 3.3, and 2 mM EGTA was added.

Electrophysiological recordings. The CA3 pyramidal neurons were visually identified by infrared video microscopy. An Axopatch 200A or a HEKA EPC-10 amplifier was used for whole-cell recordings. Patch pipettes had a resistance of 5-8 $\mathrm{M} \Omega$ when filled with the following solution (in mM): 140 Cs-methanesulfonate (CsMs), $2 \mathrm{MgCl}_{2}$, and $10 \mathrm{HEPES}, \mathrm{pH}$ 7.2, with CsOH. In some recordings, 2 mM EGTA and 5 mM MgATP were included in the pipette filling solution. The recorded voltage was corrected for a calculated $-13 \mathrm{mV}$ liquid junction potential. Assuming a 0.3 permeability ratio of bicarbonate versus $\mathrm{Cl}^{-}$, the calculated and experimentally verified reversal potential of $\mathrm{GABA}_{\mathrm{A}} \mathrm{R}$-mediated currents is $\sim-70-75 \mathrm{mV}$ under the present conditions (Sipilä et al., 2005). Field potential recordings were performed using a custom-made amplifier and a glass-capillary electrode (tip diameter 5-10 $\mu \mathrm{m}$ ) filled with a $150 \mathrm{~mm}$ $\mathrm{NaCl}$ solution and placed in the stratum pyramidale of area CA3.

Drugs. 2,3-Dioxo-6-nitro-1,2,3,4-tetrahydrobenzo[f] quinoxaline-7sulfonoamide (NBQX), bicuculline methobromide, 6-imino-3-(4methoxyphenyl)-1(6H)-pyridazinebutanoic acid hydrobromide (SR 95531; gabazine), (1,2,5,6-Tetrahydropyridin-4-yl)methylphosphinic acid (TPMPA), tetrodotoxin citrate (TTX), N-[3-([1,1-Biphenyl]-4yloxy)-3-(4-fluorophenyl)propyl]- $N$-methylglycine (NFPS) and bumetanide were from Tocris Bioscience. Picrotoxin, strychnine hydrochloride, and EGTA were from Sigma-Aldrich. Glycine was from Merck and Abcam. D,L-AP-5 and AP-5 were from Tocris Bioscience and Abcam. NBQX was used at a concentration of $10-50 \mu \mathrm{M}$ and AP-5 at 20-80 $\mu \mathrm{M}$. The concentrations for the other drugs used are given in Results.

Analyses. Data were low-pass-filtered at $1.6-5 \mathrm{kHz}$, digitized at 5-20 $\mathrm{kHz}$ via Axon Digidata 1322A and National Instruments PCI-6221 boards and analyzed using Clampfit (Molecular Devices), Strathclyde Electrophysiology WinEDR (John Dempster, Glasgow), IBM SPSS Statistic (IBM) and SigmaPlot (Systat Software) programs.

For construction of current-voltage plots, single-channel currents were detected using WinEDR event detection algorithm with a threshold set at $8 \mathrm{SD}$ from baseline current amplitude after the raw signals were low-pass filtered at $100 \mathrm{~Hz}$ (Gaussian filter used by WinEDR). The $8 \mathrm{SD}$ threshold range was $0.5-2.4 \mathrm{pA}$. The detected events were aligned by the preceding instantaneous baseline current and all-point histograms computed (Fig. 1E). The histograms had at least two peaks to which Gaussians were fitted. If multiple peaks were seen, the dominant one and the peak farthest away from it were chosen for the fit. A possible contribution of overlapping single-channel conductances was excluded by visual analysis of the recorded signals. The difference between the mean values of the fitted Gaussians was used as an estimate of single-channel currents at various holding potentials for current-voltage plots. Rough estimates for single-channel conductances were taken as chord conductances within the -10 to $20 \mathrm{mV}$ voltage range from the current-voltage plots.

The all-point histograms used in the analyses of drug effects on GlyRmediated currents were obtained from 10 to $60 \mathrm{~s}$ epochs under each experimental condition. Recording segments containing relatively stable baselines were chosen for the analyses. However, in some recordings, slow fluctuations in the baseline current were unavoidable and multiple $\geq 10 \mathrm{~s}$ epochs were averaged. In Figures $1 D, 2 D$, and $4 A-D$, the peak of each histogram was taken as $0 \mathrm{pA}$ current level to facilitate the comparison of effects of different experimental conditions on the positive "tail" reflecting GlyR-mediated single-channel currents.

Spontaneous GABAergic postsynaptic currents (sGABA-PSCs) are seen as a positive tail in the all-point histograms. When the tail was seen, (Fig. $3 B, D$ ), bins with less than half of the maximum amplitude were excluded from the positive side when fitting the Gaussians.

Unit spikes and field GDPs (fGDPs) were detected from the field potential signal using an amplitude threshold individually chosen for each recording. Sometimes the terms GDP and fGDP have been used in describing the network events seen in intracellular and extracellular recording, respectively. We use the term fGDP to specifically refer to the network events recorded with field-potential electrodes. The duration of averaged fGDPs was taken as the time between voltages at $10 \%$ of the peak amplitude during event onset and decay.

Bandpass filtering (BP) was used to highlight population events in the illustrations. Unless otherwise stated, data are presented as mean \pm SEM; quantitative comparisons were based on Wilcoxon matched-pair signed rank test, and $p<0.05$ was considered statistically significant.

\section{Results \\ Endogenous activation of strychnine-sensitive nonsynaptic GlyRs in neonatal CA3 pyramidal neurons}

In voltage-clamp recordings at $0 \mathrm{mV}$ with the low-chloride pipette solution (see Materials and Methods), bicuculline blocked sGABA-PSCs and reduced the holding current (Sipilä et al., 2005). However, spontaneous outward current transients could still be observed in the neonatal CA3 pyramidal neurons within the entire age range of the present study ( $\mathrm{P} 0-\mathrm{P} 6)$. These events were more readily detectable after low-pass filtering the traces at $100 \mathrm{~Hz}$ in 28 of 31 experiments (Fig. 1A). A closer look at the events revealed that they were spontaneous openings of single channels (Fig. 1B) which were also seen in the presence of another $\mathrm{GABA}_{\mathrm{A}} \mathrm{R}$ antagonist, SR 95531 (3-10 $\mu \mathrm{M} ; n=11$; not illustrated).

The spontaneous currents were inhibited by $1 \mu \mathrm{M}$ strychnine (Fig. 1C). In all-point histograms, this was seen as a reduction (94 $\pm 4.8 \%)$ of the tail exceeding 2 SD of the Gaussian fits $(n=6$, $p=0.028$; Fig. $1 D)$. The peak of the all-point histogram reflecting the baseline current did not change $(0.3 \pm 0.4 \mathrm{pA} ; p=0.42 ; n=$ 6) following addition of strychnine. The single-channel currents were also blocked by $100 \mu \mathrm{M}$ picrotoxin $(n=6)$ but they were seen in all further experiments that were performed in the presence of the "GABA $\mathrm{R}_{\mathrm{C}}$ " antagonist TPMPA $(50 \mu \mathrm{M} ; n=5)$, the AMPA/kainate receptor antagonist $\operatorname{NBQX}(n=8)$, and the NMDAR antagonist AP-5 $(n=8)$. These data demonstrate the presence of a robust, endogenous activation of $\mathrm{Cl}^{-}$permeable GlyRs in the immature CA3 pyramidal neurons. The input resistance of P0, P3, P4, and P5 neurons was $1550 \pm 240 \mathrm{M} \Omega(n=$ 6), $1400 \pm 380 \mathrm{M} \Omega(n=6), 1060 \pm 180 \mathrm{M} \Omega(n=28)$, and $590 \pm$ $95 \mathrm{M} \Omega(n=8)$, respectively. The membrane capacitance of $\mathrm{P} 0$, P3, P4, and P5 neurons was $19 \pm 3.2 \mathrm{pF}(n=6), 21 \pm 6.4 \mathrm{pF}(n=$ $6), 30 \pm 3.5 \mathrm{pF}(n=28)$, and $31 \pm 6.1 \mathrm{pF}(n=8)$, respectively. 
A

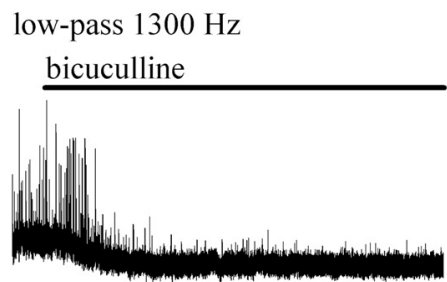

B low-pass $1300 \mathrm{~Hz}$

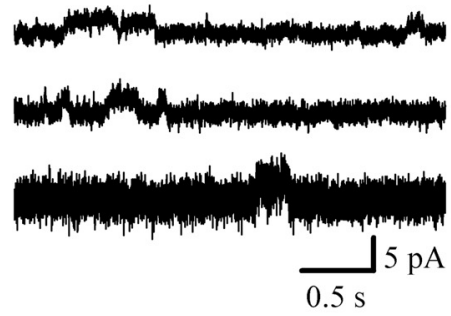

C
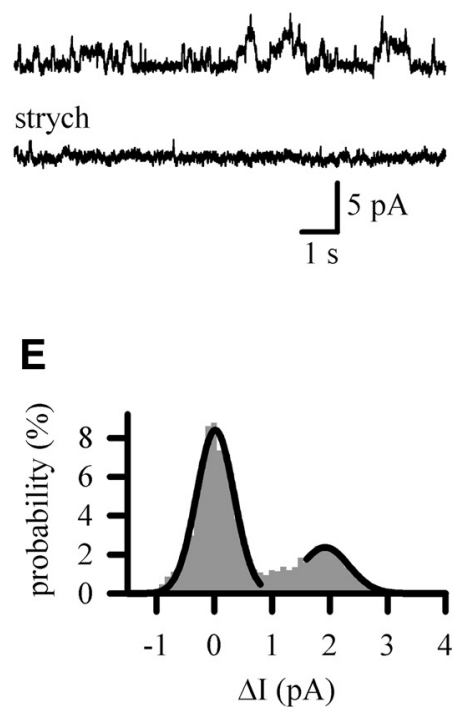

low-pass $100 \mathrm{~Hz}$

bicuculline

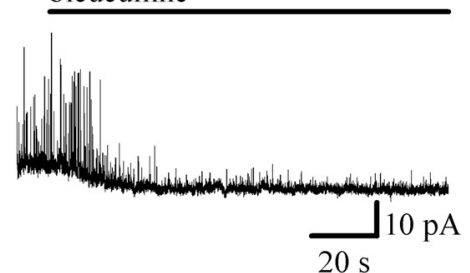

low-pass $100 \mathrm{~Hz}$

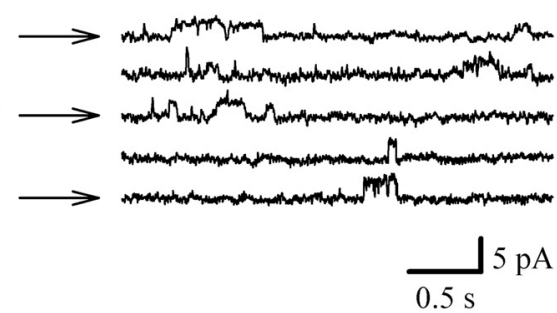

D

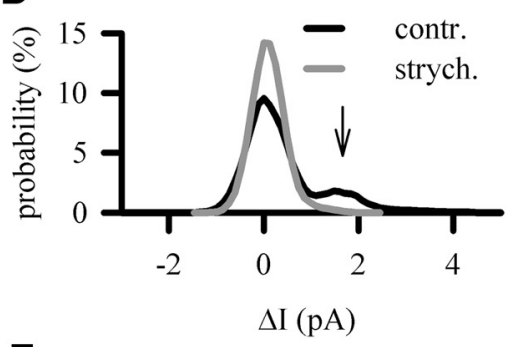

$\mathbf{F}$

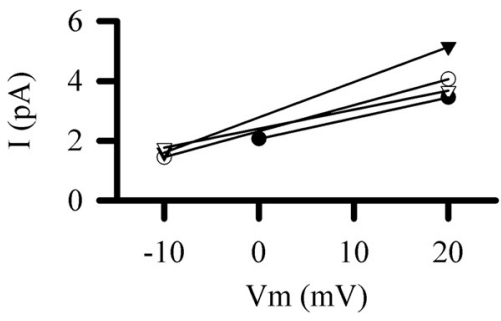

Figure 1. Nonsynaptic GlyR activation in neonatal CA3 pyramidal neurons. $\boldsymbol{A}$, Bicuculline (10 $\mu \mathrm{m})$ blocks sGABA-PSCs and reduces the baseline holding current. $B$, Spontaneous events reflecting single-channel openings are seen in the presence of $10 \mu \mathrm{m}$ bicuculline and they are more readily detectable after low-pass filtering ( $\boldsymbol{A}$ and $\boldsymbol{B}$, right). $\boldsymbol{C}$, The single-channel openings are blocked by $1 \mu \mathrm{m}$ strychnine. $\boldsymbol{D}$, An all-point histogram obtained from the recording in $\boldsymbol{C}$ shows that the smaller peak (arrow) reflecting the single-channel openings is blocked by strychnine. The histograms were aligned by their peaks ( $0 \mathrm{pA})$. $\boldsymbol{E}$, To eliminate the effects of fluctuations in the baseline current, single-channel events were detected and aligned by the instantaneous baseline current preceding the event. All-point histograms and Gaussian fits were calculated from the aligned events. $\boldsymbol{F}, I-V$ plot of the single-channel currents from four recordings depicted using distinct symbols. Single-channel currents were obtained from allpoint histograms of the kind shown in $\boldsymbol{E}$. Chord conductances were taken from the data as shown by the lines.

We estimated the single-channel conductance of the strychnine-sensitive currents from all-point histograms (Fig. 1E) obtained from epochs of primary recordings $(n=4)$ at various holding potentials (see Materials and Methods). We used data points with a distance of $30 \mathrm{mV}$ (in one case $20 \mathrm{mV}$ ) for quantification of the single-channel conductances. The results on these chord conductance measurements (Fig. $1 F$ ) yielded estimates of 60-120 pS, which are similar to the previously reported values for $\mathrm{Cl}$ - permeable GlyRs (Takahashi and Momiyama, 1991).

Inhibition of GlyT1 enhances the frequency of GlyR openings In the presence of bicuculline, AP-5 and TTX, 10-30 $\mu \mathrm{M}$ glycine increased the holding current in a dose-dependent manner
$(0.89 \pm 0.94 \mathrm{pA}$ and $15.2 \pm 5.1 \mathrm{pA}$ increase in the peak of the all-point amplitude histogram by 10 and $30 \mu \mathrm{M}$ glycine, respectively; $n=4 ; p=0.039$; Friedman test; Fig. $2 A, B)$. The SD of the Gaussian fit of the amplitude histograms was increased from $0.74 \pm 0.066 \mathrm{pA}$ to $1.5 \pm$ $0.22 \mathrm{pA}$ and $3.9 \pm 0.51 \mathrm{pA}$ by 10 and 30 $\mu \mathrm{M}$ glycine, respectively $(p=0.018$; Friedman test). This shows that, in the neonatal CA3 pyramidal neurons, glycine can activate nonsynaptic GlyRs.

If GlyRs are activated by endogenous glycine, the specific GlyT1 inhibitor NFPS (Guastella et al., 1992; Supplisson and Bergman, 1997; Harsing et al., 2003; Sergeeva et al., 2007; Warskulat et al., 2007) should enhance the GlyR-mediated current. In the presence of bicuculline and AP-5, $1 \mu \mathrm{M}$ NFPS consistently increased the frequency of single-channel currents (Fig. 2C). The 97.5th percentile of the allpoint histograms was at $3.6 \pm 0.8 \mathrm{pA}(n=$ 5 ) when the peak of the histogram was taken as $0 \mathrm{pA}$. This current level was increased to $6.4 \pm 1.6 \mathrm{pA}$ by NFPS $(n=5$; $p=0.043$; Fig. $2 D)$ reflecting an increase in the tail of the histograms caused by the enhanced GlyR current. An important conclusion from this result is that GlyT1 operates in a net uptake mode under the present control conditions, notably, with no added glycine in the superfusion solution. Furthermore, the data strongly suggest that glycine acts as an endogenous agonist of extrasynaptic GlyRs.

\section{Powerful uptake of exogenous glycine via GlyT1}

In the presence of NBQX and AP-5 (but absence of bicuculline), bath application of $30 \mu \mathrm{M}$ glycine induced a consistent increase in the baseline current (Fig. 3A). $90 \mathrm{~s}$ after the onset of glycine application, the holding current increased by $4.1 \pm 1.4$ pA $(p=0.03, n=6)$ with no further change at $240 \mathrm{~s}(4.5 \pm 1.4 \mathrm{pA}$; Fig. $3 A, B)$. In the presence of $1 \mu \mathrm{M}$ NFPS, the increase in the holding current caused by $30 \mu \mathrm{M}$ glycine amounted to $124 \pm 24 \mathrm{pA}(n=5$, $p=0.003$; Fig. $3 C, D)$, which is much more than in the absence of the uptake inhibitor $(p=0.004$ in comparison in the absence vs presence of NFPS, Mann-Whitney $U$ test). This points to a powerful glycine uptake by GlyT1.

\section{Release of glycine is not activity-dependent}

Spontaneous GlyR openings were seen in the presence of $1 \mu \mathrm{M}$ TTX in four of four recordings (Fig. 4A). In all-point histograms, the 97.5th percentile was at $1.1 \pm 0.1 \mathrm{pA}(n=4)$. In these and in all of the experiments described in this section, NBQX, AP-5, and bicuculline were also present in the perfusion solution.

The endogeonous agonist activating GlyRs could be either taurine, $\beta$-alanine, or glycine (Mori et al., 2002). Thus, in the next 
A

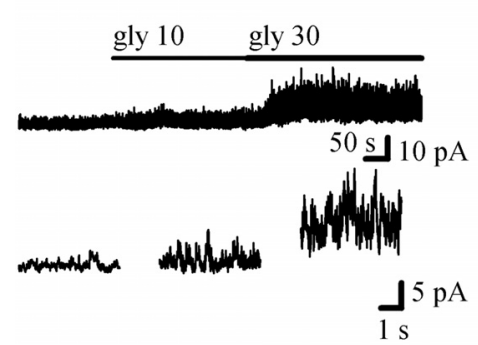

B

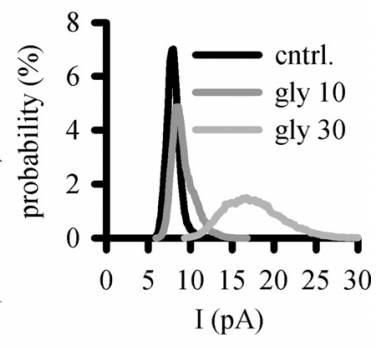

C
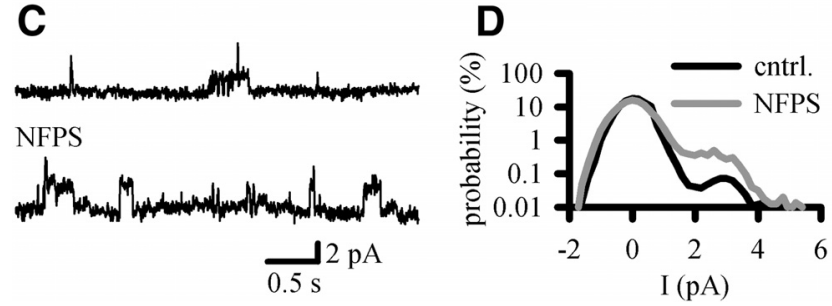

Figure 2. The frequency of GlyR openings is regulated by glycine uptake. A, Glycine (Gly, $10-30 \mu \mathrm{M}$ ) enhances the frequency of GlyR openings and, consequently, the baseline holding current in the presence of bicuculline, AP-5, and TTX. Expanded traces are shown on the bottom. $B$, An all-point histogram obtained from the recording in $A$. C, The GlyT1-specific inhibitor NFPS increases the frequency of GlyR openings (in bicuculline and AP-5). D, An all-point histogram obtained from the recording in $\mathbf{C}$ shows the increase in the GlyR-mediated current as an enhancement of the positive tail. Note that a logarithmic scale is used in the $y$-axis to highlight the tail.
A

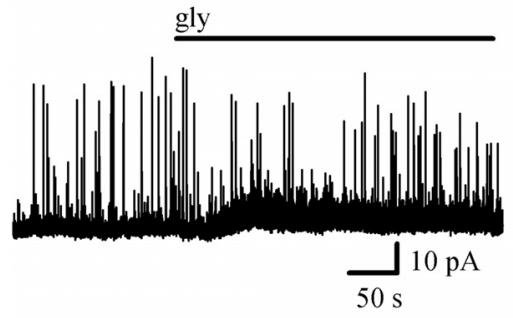

C

in NFPS

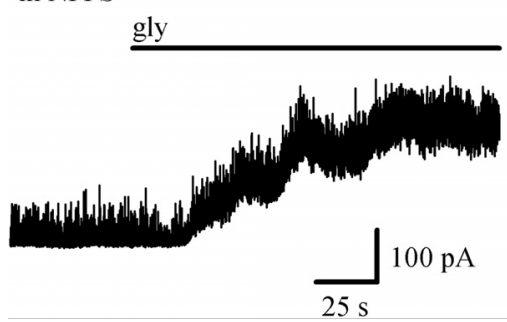

B

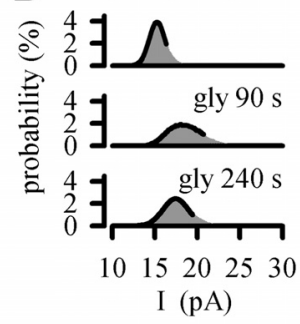

D

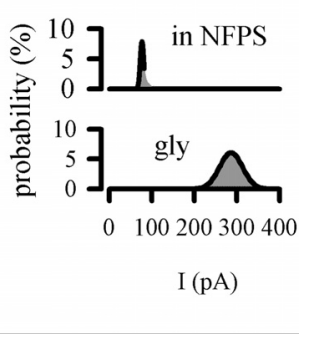

Figure 3. Powerful uptake of exogenous glycine via GlyT1.A, At $30 \mu \mathrm{M}$, glycine increases the baseline holding current in the presence of AP-5 and NBQX. $\boldsymbol{B}$, All-point histograms obtained from the recording in $A$ in control, after 90 and 240 s of the onset of glycine application. C, At 30 $\mu \mathrm{M}$, glycine has a dramatically enhanced effect on the holding current in the presence of NFPS (and AP-5 and NBQX). D, All-point histograms obtained from the recording in $\boldsymbol{C}$. Note the difference in the scale of the $x$-axis between $\boldsymbol{B}$ and $\boldsymbol{D}$.

set of experiments, $1 \mu \mathrm{M}$ NFPS was also included in the perfusion solution to specifically increase the extracellular glycine concentration. In the absence of TTX, a pronounced GlyR-mediated current was seen and in all-point histograms the 97.5th percentile was at $4.1 \pm 0.4 \mathrm{pA}(n=4$; Fig. $4 B)$. Addition of TTX had no effect on the GlyR-mediated currents because in experiments in the presence of TTX and NFPS, the 97.5th percentile was at $4.7 \pm$
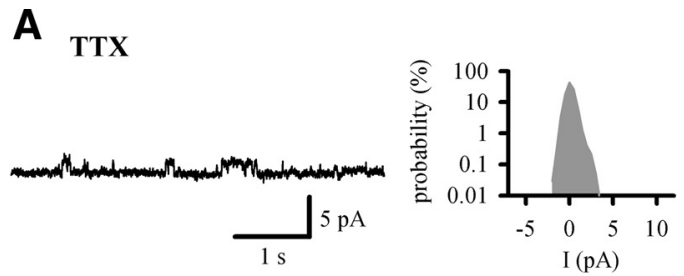

B
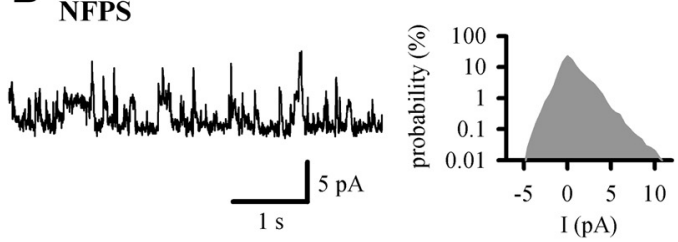

C
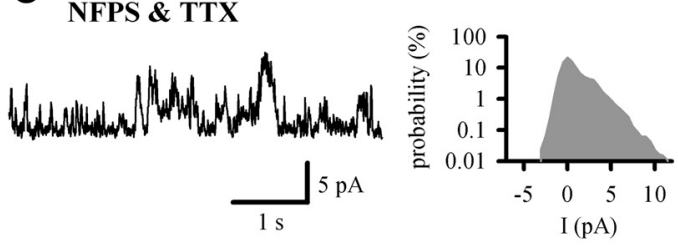

D
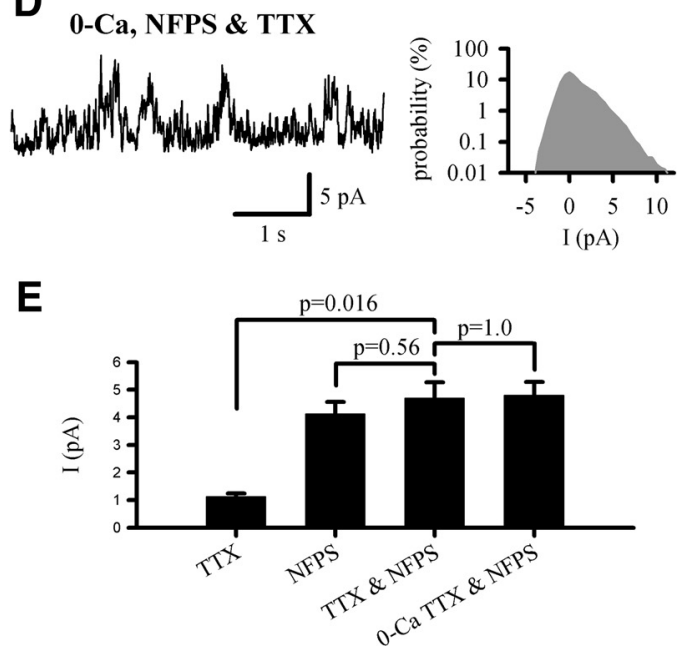

Figure 4. Release of glycine is not dependent on action potential activity or on extracellular $\mathrm{Ca}^{2+}$. $\boldsymbol{A}$, Left, GlyR single-channel currents recorded in the presence of $1 \mu \mathrm{m}$ TTX. Right, an average all-point histogram $(n=4)$. $\boldsymbol{B}$, The GlyR-mediated current is much more pronounced in recordings where $1 \mu \mathrm{M}$ NFPS is present (no TTX; left, voltage-clamp recording; right, an average all-point histogram; $n=4$ ). C, GlyR currents in the presence of NFPS and TTX (left, voltage-clamp recording; right, an average all-point histogram; $n=5$ ). $\boldsymbol{D}$, In a perfusion solution with no added $\mathrm{Ca}^{2+}$ (TTX and NFPS are also present), the GlyR-mediated current is similar to that seen in the recordings of the type shown in $\boldsymbol{B}$ (left, a voltage-clamp recording; right, an average all-point histogram; $n=5$ ). Note that the scale of the $y$-axis is logarithmic in the histograms to highlight the positive tail reflecting the GlyR currents. All experiments were performed in the presence of bicuculline, NBQX, and AP-5. $\boldsymbol{E}$, The vertical bar graph (means \pm SEM) shows the 97.5 th percentile of the all-point histograms for each recording condition with $p$ values for comparisons between groups (Mann-Whitney $U$ test; from left to right $n=4,4,5$, and 5).

$0.6 \mathrm{pA}(n=5$; Fig. $4 C ; p=0.56$ for a comparison in the absence versus presence of TTX, Mann-Whitney $U$ test; Fig. $4 E$ ). On the other hand, there was a significant difference between the group with TTX compared with TTX and NFPS ( $p=0.016$ for comparison in the absence vs presence of NFPS, Mann-Whitney $U$ test; Fig. $4 E$ ). In a further series of experiments, $\mathrm{Ca}^{2+}$ was omitted from the perfusion solution containing NFPS and TTX. All-point histograms taken from these experiments showed that the 97.5th 

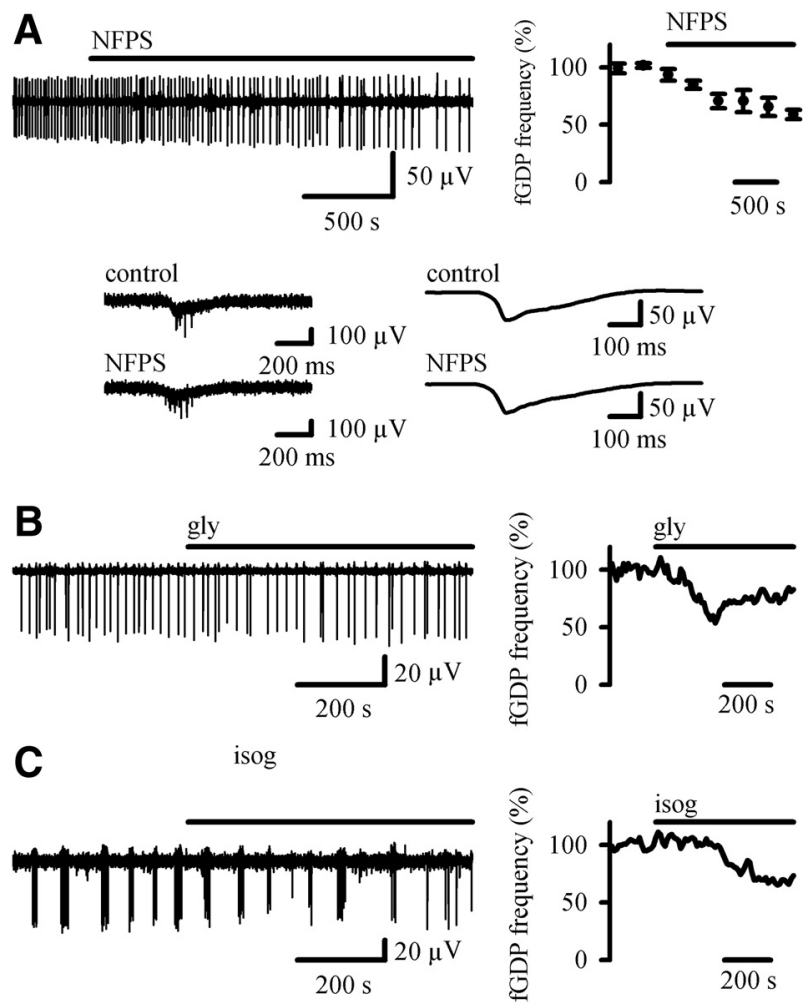

Figure 5. GlyT1 blockade inhibits fGDPs. A, Top, Left, Application of $1 \mu \mathrm{m}$ NFPS reduces fGDP frequency (BP 0.5-10 Hz) in a progressive manner. Top, Right, Pooled data on normalized fGDP frequency from five recordings of the kind shown in $\boldsymbol{A}$ as mean \pm SEM (bin width $300 \mathrm{~s}$ ). Bottom, NFPS has no effect on the number of spikes or the duration of the slow voltage shift during individual fGDPs. B, $2 \mu \mathrm{m}$ glycine inhibits fGDPs (left, field potential recording, BP $0.3-10 \mathrm{~Hz}$; right, normalized sliding-average fGDP frequency, bin width $120 \mathrm{~s}$, sliding step $10 \mathrm{~s}$, $n=9$ ). C, Isoguvacine $(0.1 \mu \mathrm{M}$ ) inhibits fGDPs (left, field potential recording, $\mathrm{BP} 0.125-10 \mathrm{~Hz}$; right, normalized sliding-average fGDP frequency, bin width 240 s, sliding step $10 s, n=5$ ).

percentile was similar to that found in the presence of $2 \mathrm{mM} \mathrm{Ca}^{2+}$ ( $4.8 \pm 0.5$ pA; Fig. $4 D ; p=1.0$ for comparison in $2 \mathrm{~mm}$ vs no added $\mathrm{Ca}^{2+}$, Mann-Whitney $U$ test; Fig. $4 E$ ). Together, these results indicate that the release of the endogenous agonist glycine is not activity-dependent in the neonatal hippocampus.

\section{GlyT1 facilitates fGDPs}

Next, we studied the effect of GlyT1 block on spontaneous activity of the neonatal hippocampus. The average fGDP frequency was $0.079 \pm 0.009 \mathrm{~Hz}(n=19)$ under control conditions. In the presence of $1 \mu \mathrm{M}$ NFPS, the frequency decreased to $59 \pm 4 \%$ of control within $25 \min (n=5, p=0.002$; Fig. $5 A)$. Neither the number of spikes during individual fGDPs $(7.0 \pm 1.1$ and $7.9 \pm$ 1.4 in control vs NFPS, respectively; $p=0.35 ; n=5$ ) nor the duration of the averaged slow voltage deflection $(420 \pm 32 \mathrm{~ms}$ and $420 \pm 29 \mathrm{~ms}$ in control vs in NFPS, respectively; $p=0.705$; $n=5$ ) were affected by the drug (Fig. $5 A$ ).

If the inhibitory effect of NFPS on fGDPs is caused by an increase in the extracellular concentration of glycine, exogenous glycine should mimic the action of the uptake blocker. Consistent with this, $2 \mu \mathrm{M}$ glycine decreased fGDP frequency to $56 \pm 11 \%$ of control within $260 \mathrm{~s}$ from the onset of application (Fig. $5 B ; n=9$; $p=0.011)$. In the presence of $1 \mu \mathrm{M}$ strychnine, $2 \mu \mathrm{M}$ glycine did not affect fGDP frequency $(7.4 \pm 13 \%, n=10, p=0.51)$ within the same time window (not illustrated).

An intriguing question is whether the inhibitory effect described above is specific for glycine. Notably, a low concentration
A
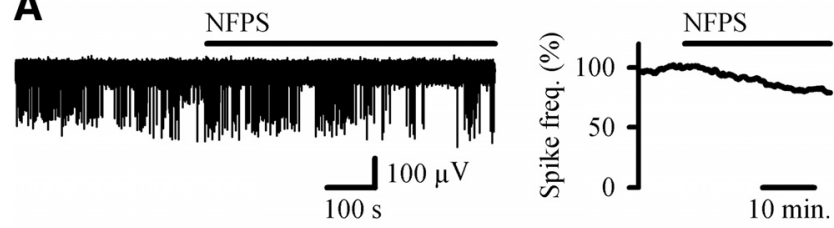

B
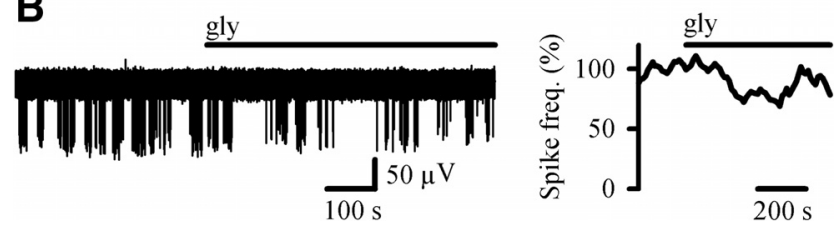

Figure 6. GlyT1 blockade inhibits spontaneous unit activity in the absence of synaptic transmission. $A$, Left, A field-potential recording showing unit activity in the CA3c stratum pyramidale and the inhibitory effect of $1 \mu \mathrm{m}$ NFPS. Right, Normalized sliding average unit spike frequency (bin width $300 \mathrm{~s}$, sliding step $10 \mathrm{~s}, n=6)$. B , Glycine $(2 \mu \mathrm{m})$ inhibits unit spikes (left, field-potential recording; right, normalized sliding average of unit spike frequency, bin width $120 \mathrm{~s}$, sliding step $10 s, n=12$ ). All experiments were performed in the presence of SR 95531, NBQX, and AP-5.

of the $\mathrm{GABA}_{\mathrm{A}} \mathrm{R}$ agonist isoguvacine $(0.1 \mu \mathrm{M})$ decreased the mean frequency of fGDPs to $62 \pm 14 \%$ within $530 \mathrm{~s}$ from the onset of application $(n=5 ; p=0.043$; Fig. $5 C)$. Within 10 min after washout of the drug, fGDP frequency recovered back to the control level ( $93 \pm 8 \% ; n=5$ ). This is in line with our earlier, and at that time somewhat surprising finding that GDP frequency is suppressed following inhibition of GABA uptake (Sipilä et al., 2004).

\section{GlyT1 facilitates unit activity in the absence of} synaptic transmission

We wanted to test whether GlyT1 block and glycine act in a nonsynaptic manner on the spontaneous activity of neonatal hippocampal neurons. Glycine-mediated actions on NMDARs were excluded by $20 \mu \mathrm{M}$ AP-5. GABA A $_{\mathrm{A}}$ and AMPA-kainate receptors were blocked by $1 \mu \mathrm{M}$ SR 95531 and $10 \mu \mathrm{M}$ NBQX, respectively. Because blocking $\mathrm{GABA}_{\mathrm{A}}$ Rs inhibits unit activity, the extracellular $\mathrm{K}^{+}$concentration was raised to $6-7 \mathrm{mM}$ to promote spontaneous spikes (Sipilä et al., 2005). To avoid confounding effects associated with intracellular recordings (Tyzio et al., 2003), we used extracellular recordings to detect unit activity. Under these conditions, the average unit spike frequency was $0.85 \pm 0.2 \mathrm{~Hz}$ ( $n=19$ recordings, in 18 slices) in the CA3c stratum pyramidale. $1 \mu \mathrm{M}$ NFPS reduced spike frequency to $78 \pm 6.2 \%$ of the control level at $27 \mathrm{~min}$ from the onset of application (Fig. $6 A ; n=7 ; p=$ 0.018 ). This action was mimicked by $2 \mu \mathrm{M}$ glycine, which caused a peak decrease of spikes to $80 \pm 12 \%$ of the control level at $390 \mathrm{~s}$ from the onset of application (Fig. $6 B ; n=12 ; p=0.023$ ). Note that the partial recovery after the initial peak decrease in fGDPs (Fig. 5B) and unit spikes (Fig. 6B) can be explained by uptake of the exogenous glycine.

\section{Discussion}

In the present study, we demonstrate a robust activation of extrasynaptic GlyRs in CA3 pyramidal neurons of the neonatal hippocampus caused by endogenous, nonsynaptically released glycine. The conclusion that glycine acts as a major endogenous agonist of GlyRs gains strong support from the finding that the frequency of GlyR openings was facilitated by blocking glycine uptake via GlyT1. Furthermore, we show that the release of glycine is not dependent on extracellular $\mathrm{Ca}^{2+}$ ions, neuronal activ- 
ity, or reverse operation of GlyT1. At a physiological concentration of extracellular glycine, the nonsynaptic activation of GlyRs has an inhibitory action in the neonatal hippocampus.

Pharmacological inhibition of GlyT1 led to a dramatic increase in the effect of exogenous glycine, which implies a very high efficacy of uptake by the transporter. The increase in nonsynaptic GlyR current caused by the transport blocker NFPS indicates that GlyT1 operates in a net uptake mode in neonatal hippocampal slices even under conditions where the physiological solution is devoid of added glycine and, therefore, acts as an infinite sink of the transporter's substrate. Furthermore, this result implies that endogenous glycine acts as a physiologically relevant agonist of GlyRs, although our results do not rule out additional roles for $\beta$-alanine and taurine (Mori et al., 2002). The enhanced GlyR current caused by GlyT1 inhibition was not affected by TTX or the $0-\mathrm{Ca}^{2+}$ solution indicating that the release of glycine is not dependent on neuronal activity.

A striking finding in the present study was that a low level of nonsynaptic GlyR ( $2 \mu \mathrm{M}$ glycine or GlyT1 block) or $\mathrm{GABA}_{\mathrm{A}} \mathrm{R}$ activation ( $0.1 \mu \mathrm{M}$ isoguvacine) is inhibitory, although the anion gradients provide a depolarizing driving force in the neonatal CA3 pyramidal cells (Sipilä et al., 2006b; Ben-Ari et al., 2007). The inhibitory effect of glycine on unit spikes in the pyramidal cell layer was seen in the absence of NMDA, AMPA and GABA receptor-mediated transmission, indicating a cell-autonomous nonsynaptic mode of action. Together, these data indicate that the inhibitory action of a low tonic conductance can be achieved by activation of glycine and GABA receptors. Interestingly, the effects of extracellular glycine are promoted under conditions where RNA editing results in high-affinity GlyRs (Eichler et al., 2008).

In previous work on the neonatal hippocampus, a large increase in conductance after an initial depolarizing and excitatory transient following exposure to relatively high $\mathrm{GABA}_{\mathrm{A}} \mathrm{R}$ agonist concentrations was thought to be necessary for shunting inhibition to occur (Khalilov et al., 1999; Lamsa et al., 2000). We now show that a functionally inhibitory effect can occur at much lower conductance levels which do not evoke an initial excitatory network response. This effect most likely went unnoticed in previous studies because low agonist concentrations were not tested.

The functionally inhibitory action of the low level of GlyR or $\mathrm{GABA}_{\mathrm{A}} \mathrm{R}$ activation can be explained as follows. Our previous work shows that immature CA3 pyramidal cells act as conditional pacemakers in GDP generation by firing intrinsic bursts in a depolarized window of membrane voltage (Sipilä et al., 2005, 2009). Both synaptic and nonsynaptic GABAergic depolarization can be excitatory in neonatal pyramidal neurons if the change in membrane voltage is sufficient to activate a persistent $\mathrm{Na}^{+}$current (I-Nap) that triggers a burst of action potentials (Sipilä et al., 2006a; Valeeva et al., 2010). Assuming a $10 \mathrm{mV}$ depolarizing driving force for GlyRs (Sipilä et al., 2006b; Valeeva et al., 2013), activation of a single channel would cause $\sim 1 \mathrm{mV}$ change in the membrane potential of a cell with a $1 \mathrm{G} \Omega$ input resistance. On the other hand, the single-channel conductance of GlyRs $(\sim 60-120$ pS) was $\sim 4-19 \%$ of the total membrane conductance $(\sim 625-$ $1666 \mathrm{pS}$ which corresponds to $600-1600 \mathrm{M} \Omega$ ) of the neonatal neurons recorded in the present study. Hence, the shunting inhibitory action is likely to outweigh the slight depolarizing action of a single or a few temporally overlapping GlyR openings on the cell membrane, thereby generating a net inhibitory action under the present conditions.

GABAergic interneurons, especially those with long-range connections, have been shown to be crucial in synchronizing the activity of pyramidal cells in GDP generation (Bonifazi et al., 2009). This is achieved via both inhibitory and excitatory GABAergic synapses in the neonatal hippocampus (Bonifazi et al., 2009). In light of the present and previous data, it is likely that this dual action of the GABAergic synapses depends not only on the variability in the reversal potential of postsynaptic $\mathrm{GABA}_{\mathrm{A}} \mathrm{Rs}$ (Tyzio et al., 2006) but also on the magnitudes of both I-Nap (Sipilä et al., 2006a; Valeeva et al., 2010) and the postsynaptic $\mathrm{GABA}_{\mathrm{A}} \mathrm{R}$ conductance.

Together, our data indicate that neonatal hippocampal neurons are highly sensitive to physiological levels of glycine that have been measured in the brain extracellular and CSFs (Choi et al., 1999; Korman and Gutman, 2002). Although the effects of glycine are mediated via both the GlyRs and NMDARs, the former respond to a much wider concentration range of glycine. Hence, extrasynaptic GlyRs may participate in sensing overt physiological changes in extracellular glycine, such as those that take place during fasting and feeding (Applegarth and Poon, 1975; Karnani et al., 2011).

\section{References}

Applegarth DA, Poon S (1975) Interpretation of elevated blood glycine levels in children. Clin Chim Acta 63:49-54. CrossRef Medline

Ben-Ari Y, Cherubini E, Corradetti R, Gaiarsa JL (1989) Giant synaptic potentials in immature rat CA3 hippocampal neurones. J Physiol 416:303325. Medline

Ben-Ari Y, Gaiarsa JL, Tyzio R, Khazipov R (2007) GABA: a pioneer transmitter that excites immature neurons and generates primitive oscillations. Physiol Rev 87:1215-1284. CrossRef Medline

Betz H, Laube B (2006) Glycine receptors: recent insights into their structural organization and functional diversity. J Neurochem 97:1600-1610. CrossRef Medline

Betz H, Gomeza J, Armsen W, Scholze P, Eulenburg V (2006) Glycine transporters: essential regulators of synaptic transmission. Biochem Soc Trans 34:55-58. CrossRef Medline

Blaesse P, Airaksinen MS, Rivera C, Kaila K (2009) Cation-chloride cotransporters and neuronal function. Neuron 61:820-838. CrossRef Medline

Bolea S, Avignone E, Berretta N, Sanchez-Andres JV, Cherubini E (1999) Glutamate controls the induction of GABA-mediated giant depolarizing potentials through AMPA receptors in neonatal rat hippocampal slices. J Neurophysiol 81:2095-2102. Medline

Bonifazi P, Goldin M, Picardo MA, Jorquera I, Cattani A, Bianconi G, Represa A, Ben-Ari Y, Cossart R (2009) GABAergic hub neurons orchestrate synchrony in developing hippocampal networks. Science 326:1419-1424. CrossRef Medline

Brickley SG, Mody I (2012) Extrasynaptic GABA(A) receptors: their function in the CNS and implications for disease. Neuron 73:23-34. CrossRef Medline

Chattipakorn SC, McMahon LL (2002) Pharmacological characterization of glycine-gated chloride currents recorded in rat hippocampal slices. J Neurophysiol 87:1515-1525. Medline

Choi YH, Chang N, Anderson GH (1999) An intragastric amino acid mixture influences extracellular amino acid profiles in the lateral hypothalamic area of freely moving rats. Can J Physiol Pharmacol 77:827-834. CrossRef Medline

Demarque M, Represa A, Becq H, Khalilov I, Ben-Ari Y, Aniksztejn L (2002) Paracrine intercellular communication by a $\mathrm{Ca}^{2+}$ and SNAREindependent release of GABA and glutamate prior to synapse formation. Neuron 36:1051-1061. CrossRef Medline

Eichler SA, Kirischuk S, Jüttner R, Schafermeier PK, Legendre P, Lehmann TN, Gloveli T, Grantyn R, Meier JC (2008) Glycinergic tonic inhibition of hippocampal neurons with depolarizing GABAergic transmission elicits histopathological signs of temporal lobe epilepsy. J Cell Mol Med 12 : 2848-2866. CrossRef Medline

Eulenburg V, Armsen W, Betz H, Gomeza J (2005) Glycine transporters: essential regulators of neurotransmission. Trends Biochem Sci 30:325333. CrossRef Medline

Farrant M, Nusser Z (2005) Variations on an inhibitory theme: phasic and tonic activation of GABA(A) receptors. Nat Rev Neurosci 6:215-229. CrossRef Medline 
Fatima-Shad K, Barry PH (1992) A patch-clamp study of GABA- and strychnine-sensitive glycine- activated currents in post-natal tissuecultured hippocampal neurons. Proc Biol Sci 250:99-105. CrossRef Medline

Flint AC, Liu X, Kriegstein AR (1998) Nonsynaptic glycine receptor activation during early neocortical development. Neuron 20:43-53. CrossRef Medline

Gaiarsa JL, Corradetti R, Cherubini E, Ben-Ari Y (1990) The allosteric glycine site of the $N$-methyl-D-aspartate receptor modulates GABAergicmediated synaptic events in neonatal rat CA3 hippocampal neurons. Proc Natl Acad Sci U S A 87:343-346. CrossRef Medline

Gomeza J, Hülsmann S, Ohno K, Eulenburg V, Szöke K, Richter D, Betz H (2003) Inactivation of the glycine transporter 1 gene discloses vital role of glial glycine uptake in glycinergic inhibition. Neuron 40:785-796. CrossRef Medline

Guastella J, Brecha N, Weigmann C, Lester HA, Davidson N (1992) Cloning, expression, and localization of a rat brain high-affinity glycine transporter. Proc Natl Acad Sci U S A 89:7189-7193. CrossRef Medline

Harsing LG Jr, Gacsalyi I, Szabo G, Schmidt E, Sziray N, Sebban C, TesolinDecros B, Matyus P, Egyed A, Spedding M, Levay G (2003) The glycine transporter-1 inhibitors NFPS and org 24461: a pharmacological study. Pharmacol Biochem Behav 74:811-825. CrossRef Medline

Ito S, Cherubini E (1991) Strychnine-sensitive glycine responses of neonatal rat hippocampal neurones. J Physiol 440:67-83. Medline

Johnson JW, Ascher P (1987) Glycine potentiates the NMDA response in cultured mouse brain neurons. Nature 325:529-531. CrossRef Medline

Karnani MM, Apergis-Schoute J, Adamantidis A, Jensen LT, de Lecea L, Fugger L, Burdakov D (2011) Activation of central orexin/hypocretin neurons by dietary amino acids. Neuron 72:616-629. CrossRef Medline

Keck T, Lillis KP, Zhou YD, White JA (2008) Frequency-dependent glycinergic inhibition modulates plasticity in hippocampus. J Neurosci 28: 7359-7369. CrossRef Medline

Khalilov I, Dzhala V, Ben-Ari Y, Khazipov R (1999) Dual role of GABA in the neonatal rat hippocampus. Dev Neurosci 21:310-319. CrossRef Medline

Korman SH, Gutman A (2002) Pitfalls in the diagnosis of glycine encephalopathy (non-ketotic hyperglycinemia). Dev Med Child Neurol 44:712720. CrossRef Medline

Lamsa K, Palva JM, Ruusuvuori E, Kaila K, Taira T (2000) Synaptic GABA(A) activation inhibits AMPA-kainate receptor-mediated bursting in the newborn (P0-P2) rat hippocampus. J Neurophysiol 83:359-366. Medline

Leinekugel X, Khazipov R, Cannon R, Hirase H, Ben-Ari Y, Buzsáki G (2002) Correlated bursts of activity in the neonatal hippocampus in vivo. Science 296:2049-2052. CrossRef Medline

Lynch JW (2004) Molecular structure and function of the glycine receptor chloride channel. Physiol Rev 84:1051-1095. CrossRef Medline

Marchionni I, Omrani A, Cherubini E (2007) In the developing rat hippocampus a tonic GABAA-mediated conductance selectively enhances the glutamatergic drive of principal cells. J Physiol 581:515-528. CrossRef Medline

Mohns EJ, Blumberg MS (2008) Synchronous bursts of neuronal activity in the developing hippocampus: modulation by active sleep and association with emerging gamma and theta rhythms. J Neurosci 28:10134-10144. CrossRef Medline

Mori M, Gähwiler BH, Gerber U (2002) Beta-alanine and taurine as endogenous agonists at glycine receptors in rat hippocampus in vitro. J Physiol 539:191-200. CrossRef Medline

Owens DF, Liu X, Kriegstein AR (1999) Changing properties of GABA(A) receptor-mediated signaling during early neocortical development. J Neurophysiol 82:570-583. Medline

Scain AL, Le Corronc H, Allain AE, Muller E, Rigo JM, Meyrand P, Branchereau P, Legendre P (2010) Glycine release from radial cells modulates the spontaneous activity and its propagation during early spinal cord development. J Neurosci 30:390-403. CrossRef Medline

Semyanov A, Walker MC, Kullmann DM, Silver RA (2004) Tonically active
GABAA receptors: modulating gain and maintaining the tone. Trends Neurosci 27:262-269. CrossRef Medline

Sergeeva OA, Fleischer W, Chepkova AN, Warskulat U, Häussinger D, Siebler M, Haas HL (2007) GABAA-receptor modification in taurine transporter knockout mice causes striatal disinhibition. J Physiol 585:539-548. CrossRef Medline

Sipilä ST, Huttu K, Soltesz I, Voipio J, Kaila K (2005) Depolarizing GABA acts on intrinsically bursting pyramidal neurons to drive giant depolarizing potentials in the immature hippocampus. J Neurosci 25:5280-5289. CrossRef Medline

Sipilä ST, Huttu K, Voipio J, Kaila K (2006a) Intrinsic bursting of immature CA3 pyramidal neurons and consequent giant depolarizing potentials are driven by a persistent $\mathrm{Na}^{+}$current and terminated by a slow $\mathrm{Ca}^{2+}$ activated $\mathrm{K}^{+}$current. Eur J Neurosci 23:2330-2338. CrossRef Medline

Sipilä ST, Schuchmann S, Voipio J, Yamada J, Kaila K (2006b) The cationchloride cotransporter NKCC1 promotes sharp waves in the neonatal rat hippocampus. J Physiol 573:765-773. CrossRef Medline

Sipilä ST, Voipio J, Kaila K (2007) GAT-1 acts to limit a tonic GABA(A) current in rat CA3 pyramidal neurons at birth. Eur J Neurosci 25:717722. CrossRef Medline

Sipilä ST, Huttu K, Yamada J, Afzalov R, Voipio J, Blaesse P, Kaila K (2009) Compensatory enhancement of intrinsic spiking upon NKCC1 disruption in neonatal hippocampus. J Neurosci 29:6982-6988. CrossRef Medline

Sipilä S, Huttu K, Voipio J, Kaila K (2004) GABA uptake via GABA transporter-1 modulates GABAergic transmission in the immature hippocampus. J Neurosci 24:5877-5880. CrossRef Medline

Song W, Chattipakorn SC, McMahon LL (2006) Glycine-gated chloride channels depress synaptic transmission in rat hippocampus. J Neurophysiol 95:2366-2379. CrossRef Medline

Supplisson S, Bergman C (1997) Control of NMDA receptor activation by a glycine transporter co-expressed in Xenopus oocytes. J Neurosci 17:4580 4590. Medline

Takahashi T, Momiyama A (1991) Single-channel currents underlying glycinergic inhibitory postsynaptic responses in spinal neurons. Neuron 7:965-969. CrossRef Medline

Tyzio R, Ivanov A, Bernard C, Holmes GL, Ben-Ari Y, Khazipov R (2003) Membrane potential of CA3 hippocampal pyramidal cells during postnatal development. J Neurophysiol 90:2964-2972. CrossRef Medline

Tyzio R, Cossart R, Khalilov I, Minlebaev M, Hübner CA, Represa A, Ben-Ari Y, Khazipov R (2006) Maternal oxytocin triggers a transient inhibitory switch in GABA signaling in the fetal brain during delivery. Science 314: 1788-1792. CrossRef Medline

Valeeva G, Abdullin A, Tyzio R, Skorinkin A, Nikolski E, Ben-Ari Y, Khazipoy R (2010) Temporal coding at the immature depolarizing GABAergic synapse. Front Cell Neurosci 4:17. CrossRef Medline

Valeeva G, Valiullina F, Khazipov R (2013) Excitatory actions of GABA in the intact neonatal rodent hippocampus in vitro. Front Cell Neurosci 7:20. CrossRef Medline

Valeyev AY, Cruciani RA, Lange GD, Smallwood VS, Barker JL (1993) $\mathrm{Cl}^{-}$ channels are randomly activated by continuous GABA secretion in cultured embryonic rat hippocampal neurons. Neurosci Lett 155:199-203. CrossRef Medline

Warskulat U, Heller-Stilb B, Oermann E, Zilles K, Haas H, Lang F, Häussinger D (2007) Phenotype of the taurine transporter knockout mouse. Methods Enzymol 428:439-458. CrossRef Medline

Xu TL, Gong N (2010) Glycine and glycine receptor signaling in hippocampal neurons: diversity, function and regulation. Prog Neurobiol 91:349361. CrossRef Medline

Zafra F, Aragón C, Olivares L, Danbolt NC, Giménez C, Storm-Mathisen J (1995) Glycine transporters are differentially expressed among CNS cells. J Neurosci 15:3952-3969. Medline

Zhang LH, Gong N, Fei D, Xu L, Xu TL (2008) Glycine uptake regulates hippocampal network activity via glycine receptor-mediated tonic inhibition. Neuropsychopharmacology 33:701-711. CrossRef Medline 